\title{
PELATIHAN PENULISAN KARYA ILMIAH (Penelitian Tindakan Kelas Sebagai Inspirasi Guru Profesional)
}

\author{
Ilham ${ }^{1}$, Moh. Fauzi Bafadal ${ }^{2}$, Humaira ${ }^{3}$, Arsyad Abd Gani ${ }^{4}$, Rima Rahmaniah ${ }^{5}$ \\ 1,2,3,4,5 Pendidikan Bahasa Inggris, Universitas Muhammadiyah Mataram, ilhamsuri2015@gmail.com
}

\begin{abstract}
ABSTRAK
Abstrak: Pelatihan Penulisan Karya ilmiah ini merupakan bentuk pengabdian pada masyarakat. Kegiatan pelatihan ini fokus pada Penelitian Tindakan Kelas. Pelatihan ini bertujuan (1) memberikan pemahaman kepada guru terhadap pentingnya Penelitian Tindakan Kelas (2) para guru mampu mengaplikasikan konsep dan pemahaman Penelitian Tindakan Kelas pada pelaksanaan dan evaluasi proses pembelajaran. Lokasi kegiatan ini di Kecamatan Kopang, Kabupaten Lombok Tengah. Peserta pelatihan adalah para guru di tingkat Sekolah Dasar dan Menengah Pertama se-Kecamatan Kopang Kabupaten Lombok Tengah. Peserta yang hadir pada pelatihan ini sebanyak 35 peserta. Metode yang digunakan dalam pelatihan ini adalah ceramah bervariasi dalam bentuk seminar sehari. Peserta terlihat aktif dan semangat mengikuti pelatihan. Hal ini ditandai dengan pertanyaan yang diajukan oleh para peserta. Berdasarkan temuan hasil diskusi bahwa pelatihan penelitian tindakan kelas memberikan inspirasi tersendiri bagi guru. Kegiatan semacam ini yang jarang dilaksanakan didaerah. Peserta akan mengaplikasikan penelitian tindakan kelas dengan harapan ada proses pendampingan yang berkelanjutan.
\end{abstract}

Kata Kunci: Penelitian Tindakan Kelas, Guru Profesional.

\begin{abstract}
Training for Writing Scientific Work is a kind of community service. This training focused on Classroom Action Research. This training aimed to (1) provide the teachers comprehension to the importance of Classroom Action Research (2) teachers are able to apply the concept and comprehension of the implementation and evaluation of Classroom Action Research on learning process. This training was Located in Kopang, Central Lombok. Participants of this training were teachers at the Elementary and Junior High School level in Kopang, Central Lombok. The participants who attended in this training were 35 participants. The method used in this training was varied lectures in one day seminars. Participants were active and motivated joint this training. It was proved some questions asked by the participants. Based on the result findings of the discussion that the classroom action research training gave the teachers' inspiration for developing the learning process. This training was rarely implemented in this area. Participants will apply the classroom action research if there is a mentoring process continuously to the teachers.
\end{abstract}

Keywords: Classroom Action Research, Professional Teacher

Riwayat Artikel: Diterima: 25-11-2017, Disetujui: 13-12-2017 


\section{A. LATAR BELAKANG}

Merujuk pada Undang-Undang RI Nomor 20 Tahun 2003 tentang Sistem Pendidikan Nasional, Undang-undang RI Nomor 14 Tahun 2005 tentang Guru dan Dosen, dan Peraturan Pemerintah RI Nomor 19 Tahun 2005 tentang Standar Nasional Pendidikan, seorang guru diharapkan melakukan pengembangan dan peningkatan motivasi dan kesadaran guru sebagai tenaga professional. Untuk itu, guru dipersyaratkan untuk menguasai kompetensi sebagai agen pembelajaran dan memiliki kualifikasi akademik minimal Sarjana atau Diploma IV (S1/D-IV) yang relevan.

Kualifikasi akademik minimal S1/D-IV dibuktikan dengan ijazah dan pemenuhan persyaratan relevansi mengacu pada jejang pendidikan yang dimiliki dan mata pelajaran yang dibina. Pemenuhan persyaratan penguasaan kompetensi sebagai agen pembelajaran yang meliputi kompetensi pedagogik, kompetensi kepribadian, kompetensi sosial, dan kompetensi professional

Dalam menunjang pencapaian kompetensi yang dimaksudkan itu, seorang guru diharapkan dapat mengembangkan karya tulis ilmiah sebagai bagian dari tugas dan fungsi tenaga professional, salah satunya adalah melakukan penelitian. Penelitian yang sangat berkaitan erat dengan aktifitas seorang guru adalah penelitian tindakan kelas, merupakan aktifitas yang melekat pada diri seorang guru dimana dia senantiasa bersentuhan langsung dengan peserta didik yang diajarkannya.

Secara fakta dan aktual, seorang guru lebih mengetahui dan mendalam mengamati bagaimana keadaan dan perkembangan peserta didik. Guru bertanggungjawab atas kegiatan pembelajaran yang dilaksanakannya sehingga mereka harus menjaga kualitas pembelajarannya. Untuk itu diperlukan penelitian tindakan kelas yang dapat meningkatkan kualitas pembelajaran dengan menerapkan model pembelajaran yang inovatif.

Dengan demikian, seorang guru hendaknya juga bertanggungjawab atas pengembangan ilmunya. Agar ilmu yang diembannya dapat dikembangkan dan tidak tertinggal, guru seyogyanya melakukan kajian keilmuan yang menjadi bidangnya.

Namun pada kenyataan, para guru belum mampu memahami secara utuh dan komprehensif akan pentingnya Penelitian Tindakan Kelas. Apalagi, seorang guru diarahkan untuk melakukan pengembangan kompetensi diri dan kualitas pembelajaran.

Maka kegiatan pelatihan penulisan karya ilmiah dalam bentuk penelitian tindakan kelas ini dianggap penting sebagai sebuah strategi meningkatkan kualitas guru dan evaluasi proses pembelajaran. Guru sebagai agen perubahan iklim kelas membutuhkan pengetahuan san pengalaman yang berkelanjutan dalam mendesain pembelajaran yang menyenangkan.

\section{B. KAJIAN PUSTAKA}

\section{Guru professional}

Istilah guru profesional terdiri dari dua kata yaitu guru dan profesional. Guru menurut Ramayulis adalah seseorang yang menjalankan tugas utamanya yakni mengajar, mendidik, membimbing, mengarahkan, melatih, menilai dan mengevaluasi muridnya dalam pendidikan [7]. 
Selain itu, Nanang Purwanto mengemukakan bahwa guru adalah pendidik yang bertanggung jawab terhadap pelaksanaan pendidikan dengan sasaran peserta didik.

Selanjutnya, kata profesional berasal dari kata profesi. Secara umum profesi diartikan sebagai suatu pekerjaan yang memerlukan pendidikan lanjut sebagai dasar untuk diimplementasikan dalam berbagai kegiatan yang bermanfaat. Ramayulis menyimpulkan bahwa profesi pada hakikatnya merupakan suatu pekerjaan tertentu yang menuntut persyaratan khusus dan istimewa sehingga memperoleh kepercayaan pihak yang membutuhkan [7].

Berdasarkan penjelasan istilah antara guru dan profesional maka bisa dipahami bahwa guru professional itu memiliki tanggung jawab dalam mengembangkan kualitas pembelajaran sebagai tenaga pendidik dan juga kualitas pribadi sebagai tenaga profesional.

\section{Penelitian Tindakan Kelas}

Penelitian Tindakan Kelas (PTK) diidentikan dengan pekerjaan seorang guru dalam kelas. Sehingga keberadaan Penelitian tindakan kelas ini memiliki peran yang sangat penting bagi pengembangan guru dan proses pembelajaran. Sebagaimana yang dikemukakan oleh Kunandar bahwa Penelitian tindakan kelas adalah sebuah bentuk kegiatan refleksi diri yang dilakukan oleh para pelaku pendidikan dalam situasi pendidikan untuk memperbaiki rasionalitas dan keadilan [4].

Keterlibatan seorang guru dalam penelitian tindakan kelas membawa dampak yang baik dari praktik sosial atau pendidikan yang dilakukan. Guru secara langsung melakukan tindakan atau treatment sehingga lebih mudah memperbaiki mutu proses belajar mengajar, mengembangkan model-model variasi pengajaran dan memilih metode yang tepat dalam mendesain dan mengatur suasana kelas.

Dalam pelaksanaan kegiatan atau treatment, dibutuhkan beberapa tahapan pelaksanaan. Tahapan ini sebagai kegiatan inti dalam pelaksanaan penelitian tindakan kelas. Kemmis \& McTaggart (1988) menjelaskan empat tahapan dalam penelitian tindakan kelas. Tahapan penelitian tindakan kelas menurut [4].

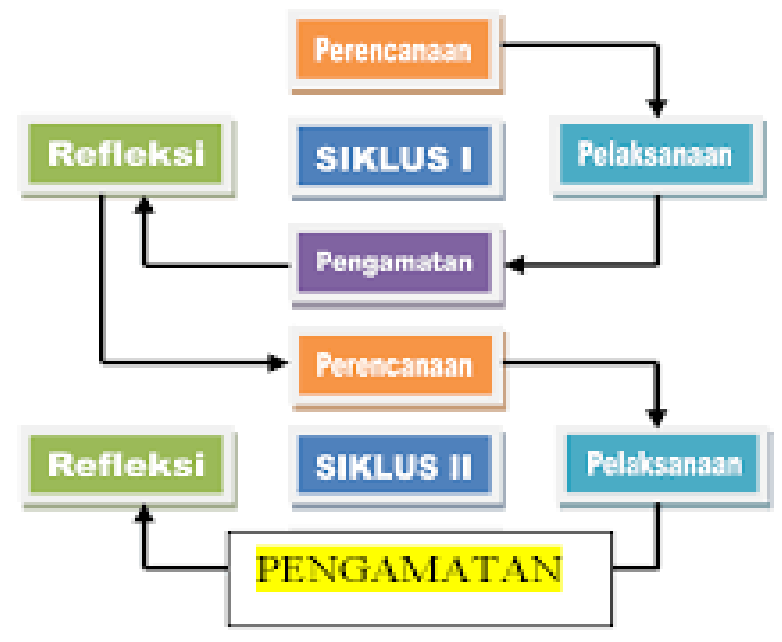

Gambar 1. Tahapan PTK 
a. Planning: tahap pertama yaitu tahapan rencana, dalam tahap ini peneliti mengidentifikasi masalah yang dihadapi peserta didik kemudian mencoba memikirkan strategi atau alternatif apa yang ditawarkan yang sesuai dengan permasalahan yang dihadapi siswa yang benar-benar memiliki peluang besar untuk bisa meningkatkan kemampuan siswa seperti yang diinginkan guru atau peneliti.

b. Action: tahap kedua yaitu tindakan, adalah dengan mengaplikasikan strategi atau alternatif yang diasumsikan dalam rencana sebelumnya dan menggunakannya dalam kelas selama proses belajar mengajar. Tindakan ini bisa dilakukan dalam tiga cycles atau tahap seperti dalam bagan diatas, tahapan tindakan bisa hanya dua cycles atau bisa juga dilanjutkan ke cycles ketiga sesuai dengan signifikansi perubahan yang ditunjukkan oleh peserta didik dalam proses belajarmengajar dengan strategi atau alternative yang ditawarkan guru atau dosen.

c. Observation: tahap ketiga merupakan pengamatan intens yang dilakukan secara sistematis selama proses berlangsung, dosen atau guru harus benar-benar mengamati perkembangan peserta didik selama proses penelitian berlangsung. Baik dari segi sikap, motivasi belajar maupun perkembangan skor atau grade pada akhirnya. Pengamatan bisa diakumulasikan dalam bentuk catatan harian (diary), bisa juga dalam bentuk dokumentasi.

d. Reflection: tahap terakhir adalah refleksi, yaitu mereview kembali, mengevaluasi, dan kemudian menjelaskan perubahan dan dampak yang terjadi pada siswa selama proses berlangsung.

\section{METODE PELAKSANAAN}

Pelaksanaan kegiatan pelatihan penulisan karya ilmiah ini dalam bentuk seminar sehari dengan menggunakan metode ceramah bervariasi.

Tahap pelaksanaan seminar sehari

\section{Presentasi}

Presentasi menurut pendapat Harmer adalah memperkenalkan sebuah situasi yang berhubungan dengan materi yang diajarkan [3]. Dalam hal ini, presentasi yang dilakukan pada pelatihan ini menjelaskan secara konsep dan teoritis maupun format dan cara pembuatan penelitian tindakan kelas.

Presentasi ini dilakukan secara berurutan dari para pembicara. Pertama, menjelaskan konsep dan teoritis serta langkah-langkah pelaksanaan penelitian tindakan kelas. Kedua, memperkenalkan format dan tata cara maupun tata tulis pembuatan laporan hasil penelitian tindakan kelas.

\section{Diskusi/ tanya jawab}

Diskusi dan tanya jawab merupakan upaya umpan balik atau feedback antara peserta dengan pembicara. Diskusi dilakukan dalam rangka memecahkan masalah, menjawab pertanyaan, memahami dan menambah pengetahuan peserta. Sedangkan tanya jawab diharapkan terjadi komunikasi secara langsung yang bersifat two way traffic sehingga terjadi dialog antara pembicara dan peserta pelatihan. 
Dalam hal ini, metode diskusi dan tanya jawab sebagai langkah untuk mengetahui penguasaan dan pemahaman peserta akan materi yang disampaikan. Dengan metode ini dapat memperoleh suatu pengertian bersama yang lebih jelas dan teliti tentang penelitian tindakan kelas.

Diskusi dan tanya jawab dilakukan dalam dua sesi. Setiap sesi memiliki memiliki pertanyaan yang berbeda. Peserta mengajukan pertanyaan yang sesuai dengan kebutuhan. Peserta belum mampu memahami secara komprehensif penelitian tindakan kelas. Peserta belum terbiasa melaksanakan penelitian tindakan kelas sehingga terlihat bingung.

\section{HASIL DAN PEMBAHASAN}

\section{Hasil}

Berdasarkasn hasil pengamatan dan diskusi, pelatihan ini sangatlah diperlukan. Pelatihan semacam ini harus dilakukan secara sistematis dan berkelanjutan. Sehingga pengetahuan peserta bias lebih terarah dan komprehensif terhadap penelitian tindakan kelas.

Hal ini terlihat dan tampak dengan jelas ketika proses diskusi dan tanya jawab berlangsung. Diskusi berjalan menarik dan tidak monoton pada satu arah dimana proses diskusi atau tanya jawab yang tidak berpusat pada seorang saja.

Ada beberapa peserta yang mengajukan pertanyaan. Salah satu contohnya adalah pak Usup Hadi, S.Pd., salah seorang guru di SMP N 3 Kopang. Dia merasa kesulitan memahami pelaksanaan penelitian tindakan kelas, dikarenakan dia belum pernah melakukan penelitian semacam ini dan pekerjaannya hanyalah mengajar saja.

\section{Pembahasan}

Pada sub bab ini membahas hasil diskusi dan tanya jawab. Proses diskusi dan Tanya jawab yang cukup menarik dimana peserta terlihat antusias dan semangat dalam mengajukan pertanyaan. Ada muncul beberapa pertanyaan peserta.

\section{Pertanyaan pertama:}

"Bagaimana cara menentukkan judul dan melaksanakan Penelitian Tindakan Kelas"

Pekerjaan sebagai seorang adalah mengajar. Setiap hari seorang guru senantiasa berkomunikasi dengan peserta didik. Berdasar pengalaman mengajar, seorang guru diharapkan bisa melakukan pemetaan masalah yang dihadapi setiap peserta didik. Dari setiap masalah ini, seorang guru bisa menentukkan dan menyimpulkan apa masalah sebenarnya yang dihadapi oleh peserta didik. Sebenarnya, judul akan muncul dengan sendirinya ketika seorang guru mampu memetakan masalah peserta didik. Dalam hal ini dibutuhkan kejelian guru dalam mengevaluasi proses dan hasil belajar peserta didik.

Dalam melaksanakan penelitian tindakan kelas ada beberapa tahapan. Pertama, perencanaan atau planning. Pada tahap ini seorang peneliti mengidentifikasi masalah yang dihadapi oleh peserta didik, lalu 
merumuskan dan merencanakan langkah-langkah strategi dalam mendesain penelitian. Kedua, tindakan atau action. Tahap kedua ini, seorang peneliti melaksanakan apa saja langkah-langkah penelitian yang direncanakan. Tindakan ini dilakukan dalam 2 siklus bahkan 3 atau lebih sehingga memenuhi pencapaian tujuan penelitian.

Ketiga, observasi atau observation. Tahap observasi ini bagi seorang peneliti merupakan tahap pengamatan secara sistematis dan berkelanjutan untuk mengamati perkembangan peserta didik selama penelitian berlangsung. Keempat, refleksi atau reflection. Tahap refleksi merpakan tahap akhir dari penelitian tindakan kelas. Pada tahap ini seorang peneliti. Pada tahap ini seorang peneliti mereview kembali, mengevaluasi dan menjelaskan perubahan yang terjadi pada setiap peserta didik.

Pertanyaan kedua:

Bagaimana caranya kita melakukan penelitian tindakan kelas sementara seorang guru dituntut untuk mengajar.

Tugas dan tanggung jawab bagi guru tidak hanya mengajar, akan tetapi juga meneliti. Hal ini termaktub dalam Undang-undang RI Nomor 14 Tahun 2005 tentang Guru dan Dosen. Penelitian yang sangat erat kaitannya dengan seorang guru adalah Penelitian Tindakan Kelas. Dalam hal ini, penelitian tindakan kelas tidak hanya dilakukan oleh salah seorang guru saja, akan tetapi, penelitian tindakan kelas bisa dilakukan secara bersama-sama atau collaborative research.

Seperti halnya pernyataan David T. Hansen bahwa we require teachers to work in teams, we ourselves work in interdisciplinary teams in an effort to understand the complexities of collaboration and develop new approaches to it. Artinya kerja tim bagi pengembangan kinerja guru itu sangat penting dan dibutuhkan. Penelitian tindakan kelas tidak hanya bias dilaksanakan oleh satu orang guru, akan tetapi lebih bagus dilaksanakan secara bersama-sama untuk mencapai tujuan bersama.

\section{E. TEMUAN}

Pelatihan penulisan karya ilmiah memang nyata-nyata dibutuhkan bagi guru guru Sekolah Dasar dan Menengah Pertama. Kebanyakan peserta mengeluhkan kurangnya pengetahuan dan pemahaman akan karya pengembangan profesi dan arti pentingnya untuk meningkatkan profesionalitas mereka sebagai guru.

Guru-guru menyadari sepenuhnya bahwa karya ilmiah penting bagi mereka sebagai bentuk perwujudan pertanggungjawaban guru. Oleh karena itu guru merasakan banyak manfaat yang diperoleh dari pelatihan ini untuk meningkatkan kemampuannya dalam menulis laporan penelitian tindakan kelas.

Sebagai seorang pendidik, mitra kesulitan dalam mendesain rancangan penelitian hingga melaksanakan dan mengevaluasi penelitian tindakan kelas. Maka dari itu, mitra mengharapkan ada proses pendampingan sehingga bisa melahirkan sebuah karya ilmiah 


\section{F. SIMPULAN DAN SARAN}

Kegiatan pelatihan penulisan karya ilmiah ini sangat urgen bagi guru sebagai pendidik. Hal ini diperlukan karena dapat membantu dan menumbuhkan kesadaran seorang guru untuk berkreatif dan inovatif dalam merancang perangkat pembelajaran dan meningkatkan proses kebiatan belajar mengajar. Selain itu, kegiatan ini dapat meningkatkan nilai dan angka kredit guru sebagai penunjang etika keprofesian. Sehingga disarankan Kegiatan pelatihan penulisan karya ilmiah sangat perlu untuk dilaksanakan secara sistematis dan berkelanjutan.

\section{UCAPAN TERIMA KASIH}

Pertama, ungkapan rasa syukur tak terhingga hanya tertuju pada Sang pemilik jiwa ini, Allah SWT, memberikan nikmat tak terbalas dengan apapun. Salam dan salawat saya sampaikan kepada Baginda Rasul Allah, membawa pencerahan bagi seru sekalian alam.

Dan tidak lupa ucapan terima kasih Tim penulis kepada Lembaga Pengabdian Pada Masyarakat (LPPM) Universitas Muhammadiyah Mataram yang telah mendanai kegiatan pengabdian ini sehingga terlaksana dengan baik.

Mudah-mudahan dengan bantuan dan penghargaan ini, meningkatkan daya kreatifitas dan inovasi dosen dalam mengembangkan tridharma Perguruan Tinggi khusus bagi dosen Universitas Muhammadiyah Mataram.

\section{DAFTAR PUSTAKA}

[1] DP2M Dikti. Panduan Pengabdian kepada masyarakat, Buku VII. Jakarta. 2009

[2] Hansen, David T. Transforming Teacher Education: Lessons in Professional Development. Bergin \& Garvey. London. 2001.

[3] Harmer, Jeremy. The Practice of English Language Teaching. Longman. Cambridge, UK. 2007

[4] Kunandar. Langkah Mudah Penelitian Tindakan Kelas sebagai Pengembangan Profesi Guru. Rajawali Press. Jakarta. 2008.

[5] LPM. Panduan Program Pengabdian Kepada Masyarakat UMM. 2017. Mataram

[6] Purwanto. Pengantar Pendidikan. Graha Ilmu. Yogyakarta. 2014.

[7] Ramayulis. Profesi dan Etika Keguruan. Kalam Mulia. Jakarta. 2013 


\section{DOKUMENTASI KEGIATAN}

Penyampaian Materi Penelitian Tindakan Kelas

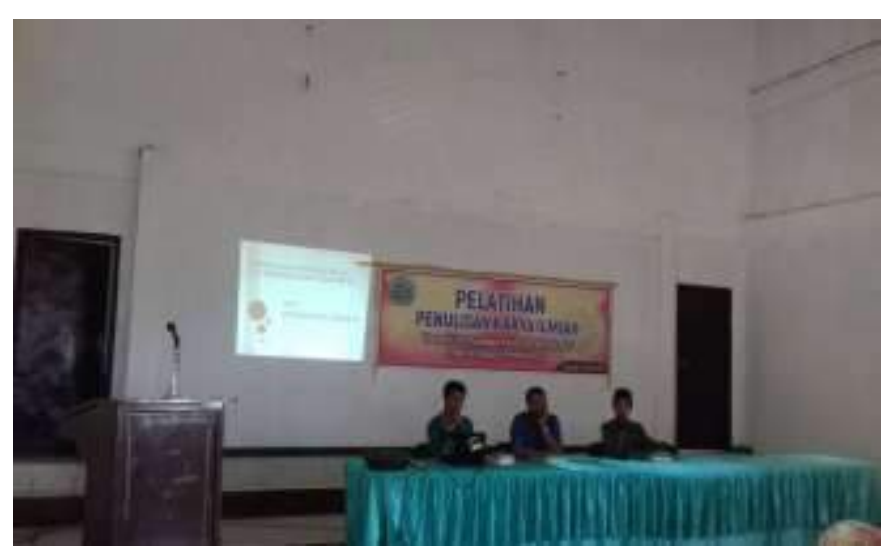

Sesi Diskusi dan Tanya Jawab
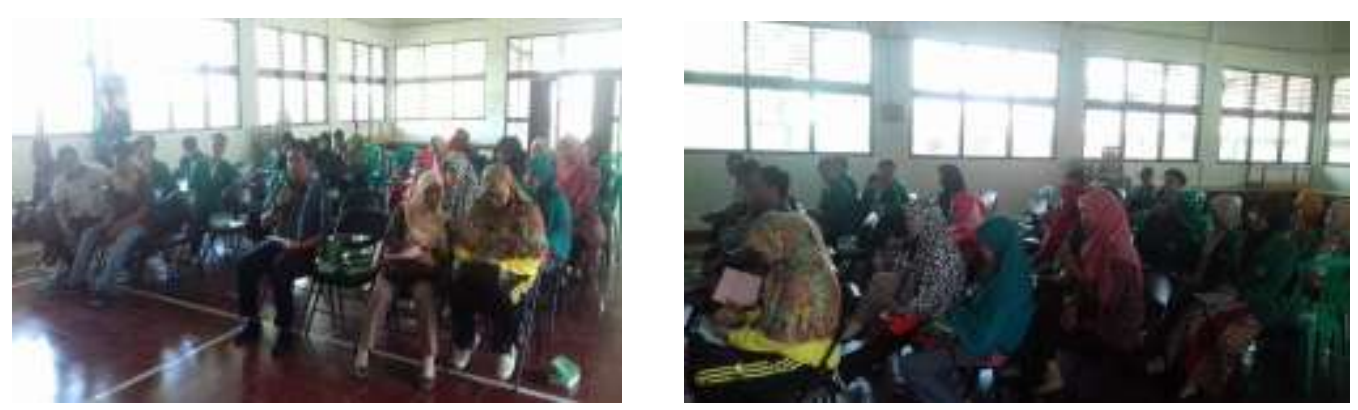